\section{Building Better Communities, One Person at a Time}

\section{David A. Tyckoson and Nicolette Warisse Sosulski}

Correspondence concerning this column should be directed to Nicolette Warisse Sosulski and David A. Tyckoson, email: librista@gmail.com and davety@csufresno.edu.

\section{WORKING WITH USERS}

\section{David A. Tyckoson}

Reference librarians, here defined as those people who answer questions for users, play a more profound role within the community than one might think. In the process of responding to users' questions, the librarian is doing much more than finding an answer to the question that was asked. The librarian is building a relationship with the user that will make the user more likely to ask more questions in the future. The answer to one question often generates more questions later-bringing the user back to the library more often than the user would have guessed at first.

Most users who come to the library seek answers or solutions to an immediate problem. The library offers help to the business person seeking investment opportunities, the gardener looking for information on the viability of new seed varieties, the immigrant wanting to improve English language skills, the college student who desires more challenging computer programming applications than are provided in class, the adult seeking information on divorce, the high school girl wanting to know at what stage a pregnancy starts to show, and the child curious about everything to do with ligers. The reference librarian helps them, providing them with information, search strategies, and websites that cover their specific topics. Some users find everything that they want, some find part of what they are looking for, and a few might not find anything useful. This is the nature of reference work, and it is what we do for our users every single day.

This description makes it seem like working with users is a simple activity, but there is something more complex going on. Uses do not submit questions (What is the meaning of life, the universe, and everything?), wait a while, then receive an answer (Forty-two). Reference librarians work together with users, and it is that togetherness that makes what we do so special. We help define the question, we work together to examine search terms, and we collaborate to evaluate the results. The librarian becomes the user's partner during the problem-solving process.

By working together, we build relationships with our users. Users learn that we give professional assistance. They also learn searching and evaluation skills that enable them to do similar searches on their own in the future. Reference librarians take user needs seriously, find sources at the appropriate reading level, and keep requests confidential. By doing so, we inspire in our users feelings of respect, knowledge, and perhaps most importantly, trust. Those feelings make it easier for a user to come in again with another question. 


\section{A REFERENCE FOR THAT}

It is this relationship that makes the biggest difference to our users. If you ask a user about their library experience several months after a visit, they probably will not remember what they asked, but they will remember whom they asked and how that librarian made them feel. And I am willing to bet that in the vast majority of cases, they would definitely go back to that librarian again with their next question. This is how I measure reference success.

That success goes on every day at every library. We help our users with their immediate requests, but in the process we are building a relationship with them that will serve them well over time. We make the library a trusted institution that they can turn to when they are in their greatest need. We ensure that they see that the library plays a key role within the community. As we help users, we are solving immediate problems-but we are also helping build a stronger community, one user at a time.

\section{NEGOTIATING THE QUESTION}

\section{Nicolette Warisse Sosluski}

This type of question negotiation and relationship building can happen quickly or gradually over time. Sometimes I have noticed it happening and sometimes it has happened without my being aware of it. How can that relationship growth happen without my knowing it, you ask? Well, for one thing, each member of library staff is being observed every day by the patrons of the library, especially the ones you might call "the regulars." They know much more about us than we do about them, because there are so many more of them. When you are helping a patron and going the extra mile, they know. When you are smiling through clenched teeth and praying that a patron will Just. Go. Away... they know that, too. So, even if your interactions with these patrons up to this point have been merely a printer jam fix or an extension of computer time, they are coming up to you because they have chosen you to answer their question. The question has a bit of intimacy to it and they have waited for just the right time-and just the right librarian.

One day, I was approached by a patron whom I recognized by sight, but didn't know personally. "I was hoping you would be here!" she said. "I need something that is kind of hard to talk about and hard to find." Her adult child lived out of state, out West, and was having a difficult time emotionally, struggling with hopelessness and needing help. The child wanted professional counseling, but was overwhelmed at the prospect, and thought it would be less daunting in an outdoor setting. This type of service does not exist where I am in the Midwest-or at least, I was unable to find it. But it is not at all uncommon in some western, outdoorsy, and (as a friend of mine calls them) "crunchy" states. The child did not know what to do, and sought parental guidance from my patron. This mother wanted to support her child, but outdoor psychotherapy referrals for a city over a thousand miles away were beyond her scope. She was worried and protective of her child, and, flatteringly, she selected me to help.

I started my search by looking at sites and articles online on psychotherapists as well as the local psychology associations and groups. I also looked at Google Scholar to see if anybody was writing about this. I saw mentions of hiking therapy, snowshoe therapy, and ski therapy-who knew?

My patron was sitting at a public computer at this point because I had told her that finding what she needed might take a bit. To my surprise, another patron sitting at a nearby computer, whom I knew even less than the woman I was assisting, leaned over to my patron and said, "Don't you worry, honey, you got this." She nodded her head at me, and added, "She doesn't stop until it is done!" Apparently, this user made a habit of listening to every patron and librarian at the desk, including the interaction I'd just had.

I then called the director of a therapy association in the area where the child lived. I asked if the association had therapists who offered these kinds of services or whether he had encountered colleagues who did at local professional meetings. He was surprised to hear from the Midwest, but readily gave me three contacts, as well as information for his own practice, and urged me to call back if the prospective client did not "click" with any of the colleagues he suggested.

I returned to the patron and gave her the information, printing a page with the clinics' contact info and cautioning her that my referrals meant that the services she sought were probably offered but were not a professional recommendation from me. She hugged me (and the encouraging patron at the public computers said "I told you!"). She had tears in her eyes. I felt I had made a difference, and a friend. I also breathed a sigh of relief that I had found something that may have merited the confidence that my patron (and the bystander) had in me. Ever since that interaction, that patron has made a point of saying "hello" when she comes into the library.

Reference librarians build these relationships knowingly and unknowingly every day, helping patrons and thus helping and strengthening our communities. It may be that we help a group or a class. Often, it is just one person. And the community is better for it. 